\title{
Pengaruh Metode Pembelajaran dan Berpikir Kreatif Terhadap Hasil Belajar Sejarah Siswa SMA
}

\author{
Oleh : Sumardiansyah Perdana Kusuma \\ Jakarta, Program Pascasarjana Universitas Negeri Jakarta \\ sumardiansyahperdana@gmail.com
}

\begin{abstract}
This research aims to investigate the impact of learning methods and creative thinking skills toward history learning outcome of students at Al-Azhar Kelapa Gading Islamic Senior High School. The method used in this research is experimental research method with the treatment design by level $2 \times 2$. The instrumen used to assess students creative thinking's skills is in quesionnaire form, while the instrument used to assess students achievement is in the multiple choice form.

The result show that: 1) history learning outcome of students using mind mapping learning methods are higher than those history learning outcomes of students using conventional learning methods, 2) there is interaction effect between learning method and creative thinking on history learning outcome of students, 3) history learning outcome of students who has high creative thinking and using mind mapping learning method are higher than students using the conventional learning method, 4) history learning outcome of students who has low creative thinking and using mind mapping method are lower than students using the conventional learning method.
\end{abstract}

Keywords : learning methods, mind mapping, conventional, history learning outcomes, creative thinking

\begin{abstract}
Abstrak
Penelitian ini bertujuan untuk mengetahui pengaruh metode pembelajaran dan kemampuan berpikir kreatif terhadap hasil belajar sejarah siswa di SMA Islam Al-Azhar Kelapa Gading. Metode penelitian yang digunakan dalam penelitian ini adalah metode eksperimen dengan desain treatment by level $2 \mathrm{x}$ 2. Instrumen berpikir kreatif berbentuk kuesioner, sedangkan instrumen hasil belajar berbentuk soal pilihan ganda.

Hasil penelitian menunjukkan bahwa: 1) hasil belajar sejarah siswa yang menggunakan metode pembelajaran peta pikiran lebih tinggi daripada hasil belajar sejarah siswa dengan menggunakan metode pembelajaran konvensional, 2) terdapat pengaruh interaksi antara metode pembelajaran dan berpikir kreatif terhadap hasil belajar sejarah siswa, 3) hasil belajar sejarah siswa yang berpikir kreatif tinggi dan menggunakan metode pembelajaran peta pikiran lebih tinggi dari siswa yang menggunakan metode pembelajaran konvensional, 4) hasil belajar sejarah siswa yang berpikir kreatif rendah dan menggunakan metode pembelajaran peta pikiran lebih rendah dari siswa yang menggunakan metode pembelajaran konvensional.
\end{abstract}

Kata kunci : metode pembelajaran, peta pikiran, konvensional, hasil belajar sejarah, berpikir kreatif 


\section{Pendahuluan}

Perkembangan zaman yang semakin modern terutama pada era globalisasi ini menuntut adanya sumber daya manusia yang berkualitas tinggi. Peningkatan kualitas sumber daya manusia merupakan prasyarat mutlak untuk mencapai tujuan pembangunan. Salah satu wahana untuk meningkatkan sumber daya manusia tersebut melalui pendidikan.

Orang perlu belajar dari sejarah dan jangan sekali-kali melupakan sejarah kareba sejarah membuat seseorang menjadi arif dan bijaksana. Sejarah mengajarkan kita bagaimana belajar dari masa lampau untuk perubahan masa depan. Machiavelli, seorang pemikir Italia, mengungkapkan pengalaman sejarah adalah guru yang baik, sebab dari sejarah didapatkan ajaran-ajaran praktis. Dimasa sekarang orang selain harus belajar dari sejarah, juga harus belajar mata pelajaran sejarah.

Tanner dan Tanner dalam Hamid Hasan $(2012,4)$ mengungkapkan kurikulum sejarah dapat dikembangkan melalui beberapa filosofi antara lain: Perenialisme, pendidikan sejarah harus mengembangkan rasa bangga terhadap bangsa dan negara; Esensialisme, pendidikan sejarah sebagai sarana untuk mengembangkan kemampuan intelektual siswa;Humanisme, pendidikan sejarah harus mampu mengembangkan kepribadian siswa; Rekonstruksi sosial, pendidikan sejarah harus mampu menyiapkan siswa untuk suatu kehidupan yang lebih baik dimasa sekarang dan masa akan datang

Terkait dengan gambaran diatas, guru sebagai pendidik mempunyai peranan penting dalam mewujudkan tujuan pendidikan menumbuhkembangkan karakter kebangsaan, kemanusiaan, dan meningkatkan hasil belajar sejarah siswa. Rosenthal dan Jacobson dalam Vern Jones dan Louise Jones (2012, 1214) memaknai hasil belajar sebagai sebuah perspektif, siswa menampilkan sebagaimana yang guru harapkan. Hasil belajar menurut Mayer dan Wittrock dalam Anderson dan Krathwohl (2010, 94-95) diterjemahkan ke dalam dua hal, yaitu meretansi dan mentransfer. Meretansi adalah kemampuan siswa untuk mengingat materi pelajaran yang sudah disampaikan. Kegiatan ini terfokus pada masa lalu dan siswa cenderung hanya mengingat sampai jangka waktu tertentu. Sedangkan mentransfer adalah kemampuan untuk menggunakan apa yang sudah disampaikan guru untuk menyelesaikan masalah-masalah baru, dan menjawab pertanyaan-pertanyaan baru. Mentransfer menitikberatkan pada masa depan, hasil belajar tidak hanya sebatas ingatan melainkan untuk dipahami dan diterapkan didalam kehidupan sehari-hari.

Gagne dalam Richey (2000: 82) menyebut hasil belajar dengan istilah kapabilitas, yaitu kemampuan yang dimiliki dan disimpan lama oleh siswa serta dapat diamati. Hasil belajar Gagne terdiri dari lima kategori yaitu, (1) informasi verbal, (2) keterampilan intelektual (3) strategi kognitif, (4) keterampilan motorik, (5) sikap. Kelima aspek ini ada pada diri setiap manusia dan dapat diukur berdasarkan pengamatan sehari-hari, terutama dalam proses pembelajaran dikelas. Reigeluth dalam Suprihatiningrum (2013: 37) mendefinisikan hasil belajar sebagai suatu kinerja yang diindikasikan sebagai suatu kemampuan yang diperoleh. Reigeluth juga membagi hasil belajar menjadi tiga indikator yaitu (1) Efektifitas pembelajaran yang bisa diukur dari tingkat keberhasilan siswa dari berbagai sudut, (2) Efisiensi pembelajaran yang bisa diukur dari waktu belajar dan biaya pembelajaran, (3) Daya tarik pembelajaran yang selalu diukur dari keinginan siswa untuk belajar secara terus menerus.

Penguasaan materi oleh guru didalam menyampaikan sebuah permasalahan didalam kelas tidaklah cukup, guru juga harus mampu menguasai dan menerapkan berbagai metode pembelajaran yang tepat dan sesuai dengan materi yang diajarkan. Metode pembelajaran yang biasa digunakan oleh guru dalam pembelajaran sehari-hari didalam kelas disebut metode pembelajaran konvensional. Killearn dalam Hamruni (2012, 73) mengungkapkan bahwa metode konvensional adalah metode 
pembelajaran secara langsung, dimana materi langsung disampaikan oleh guru.

Johnson dan Smith (2005) mengemukakan persoalan berkaitan dengan metode pembelajaran konvensional yang disebutnya terlalu berkepanjangan, yaitu (1) perhatian siswa menurun seiring berlalunya waktu, (2) hanya menarik untuk siswa yang bertipe auditori, (3) cenderung mengakibatkan kurangnya proses belajar mengenai informasi faktual, (4) mengasumsikan bahwa siswa memerlukan informasi yang sama dengan langkah penyampaian yang sama pula, (5) siswa cenderung kurang menyukainya.

Guru pada umumnya berbicara dengan kecepatan 100 hingga 200 kata per menit, hanya persoalannya adalah sejauh mana siswa mampu menangkap kata-kata yang diucapkan oleh guru. Kemampuan siswa menangkap kata-kata yang diucapkan guru dapat tergantung dari kemampuan mendengar dan konsentrasi siswa. Hasil penelitian Silberman (2013: 24) menunjukkan bahwa siswa mampu mendengarkan suara dengan kecepatan 400 hingga 500 kata per menit, dalam hal ini siswa hanya sebatas mendengarkan tanpa dibarengi proses berpikir. Ketika guru terlalu dominan dalam berbicara didalam kelas, akibatnya siswa akan jenuh dan cenderung kehilangan konsentrasi belajar.

Alat pembelajaran manusia yang mempergunakan otak dapat dibagi menjadi tiga bagian utama, yaitu kemampuan kreatif, kemampuan berpikir (nalar), dan kemampuan mengingat (memori). Pembelajaran yang bermakna seharusnya menekankan pada kemampuan kreatif dan kemampuan berpikir manusia terhadap suatu persoalan atau materi pelajaran. Kondisi ini tidak terjadi karena sistem pendidikan kita dirancang bukan untuk melatih dan mengembangkan kemampuan memori siswa, melainkan sistem pendidikan yang berbasis hafalan. Carnegie Institute dalam sebuah risetnya di Amerika menyatakan bahwa $99 \%$ orang yang sukses dalam hidupnya adalah orang-orang yang menggunakan $80 \%$ otaknya untuk kemampuan kreatif dan berpikir.
Salah satu metode yang diduga mampu membuat suasana pembelajaran yang menarik, memotivasi siswa dan menyenangkan ketika siswa mempelajari materi sejarah adalah peta pikiran. Peta pikiran merupakan suatu metode pembelajaran yang sangat baik digunakan oleh guru untuk meningkatkan daya hafal, pemahaman konsep, serta dapat meningkatkan daya kreatifitas melalui kebebasan berimajinasi.

De Porter dan Hernacki (2013: 153) mendefinisikan peta pikiran sebagai tehnik pemanfaatan keseluruhan otak dengan menggunakan citra visual dan prasarana grafis lainnya untuk membentuk kesan. Hal ini dikuatkan oleh Wycoff (2004: 41), menulis catatan dengan cara memetakan pikiran membutuhkan keterlibatan dengan bahan pelajaran yang tentu saja menghasilkan pola ingatan yang kuat.Menurut Buzan (2004: 17) dalam teorinya "Basic Ordering Ideas", tatanan ide dasar adalah kunci untuk membentuk dan mengarahkan proses belajar kreatif dari asosiasi. Bagi Hyerle (2012: 1) peta pikiran adalah sebuah bahasa, bahasa kognisi visualverbal sehingga memungkinkan suatu kapasitas yang lebih mendalam untuk melihat, mengubah, membayangkan, dan meningkatkan kemampuan berpikir.Singer dalam Hyerle (2012: 43) menjelaskan peta pikiran sebagai perangkat untuk mengembangkan fungsi pelaksana dan metakognitif kebiasaan berpikir siswa. Penggunaan peta pikiran akan mendorong setiap individu untuk mengembangkan keterampilan berpikir yang kreatif untuk memunculkan ide-ide terbaik.

Halpern (2005) mengungkapkan kemampuan berpikir kreatif sebagai proses berpikir untuk menghasilkan gagasan-gagasan baru dan berguna atau new ideas and useful. Krist dalam Munandar (2009: 33), pribadi kreatif mampu mempertahankan sikap bermain-main dengan masalah serius dalam kehidupan. Keadaan ini membuat seseorang kreatif mampu melihat sebuah permasalahan dengan cara yang segar, unik, dan inovatif. Bagi Jewel dalam Kuswana (2012: 208-209) 
untuk mengidentifikasikan karakteristik penalaran anak berbakat salah satunya adalah berpikir kreatif. Menurut Cropley dalam Nurhayati (2011: 82) kecakapan kemampuan berpikir kreatif adalah kecakapan menciptakan gagasan, mengenal kemungkinan alternatif, melihat kombinasi yang tidak diduga, dan memiliki keberanian untuk mencoba sesuatu yang tidak biasa. Hal ini dikuatkan oleh Bono dalam Suharnan (2005: 380) yang mengartikan berpikir kreatif sebagai berpikir lateral. Berpikir lateral adalah cara berpikir yang berusaha mencari alternatif lain dalam memandang suatu masalah, dan tidak terpaku pada caracara yang sudah ada didalam memperbaiki atau menyelesaikan masalah.

Penelitian ini bertujuan mengetahui:

1) Perbedaan hasil belajar sejarah antara siswa yang mengikuti metode pembelajaran peta pikiran dan metode pembelajaran konvensional,
2) Pengaruh interaksi antara metode pembelajaran dan berpikir kreatif terhadap hasil belajar sejarah,

3) Perbedaan hasil belajar sejarah antara siswa dengan kemampuan berpikir kreatif tinggi yang mengikuti metode pembelajaran peta pikiran dan siswa yang mengikuti metode pembelajaran konvensional,

4) Perbedaan hasil belajar sejarah antara siswa dengan kemampuan berpikir kreatif rendah yang mengikuti metode pembelajaran peta pikiran dan siswa yang mengikuti metode pembelajaran konvensional.

\section{Metodologi Penelitian}

Metode penelitian yang digunakan dalam penelitian ini adalah metode eksperimen yang digambarkan sebagai berikut :

Tabel Eksperimen Desain Treatmentby Level 2 × 2

\begin{tabular}{|l|c|c|}
\hline \multirow{2}{*}{$\begin{array}{c}\text { Kemampuan } \\
\text { Berpikir Kreatif (B) }\end{array}$} & \multicolumn{2}{|c|}{ Metode Pembelajaran ( A ) } \\
\cline { 2 - 3 } & $\begin{array}{c}\text { Metode Pembelajaran Peta } \\
\text { Pikiran }\left(\mathrm{A}_{1}\right)\end{array}$ & $\begin{array}{c}\text { Metode Pembelajaran } \\
\text { Konvensional (A) }\end{array}$ \\
\hline $\begin{array}{l}\text { Kemampuan Berpikir } \\
\text { Kreatif Tinggi (B) }\end{array}$ & $\mathrm{A}_{1} \mathrm{~B}_{1}$ & $\mathrm{~A}_{2} \mathrm{~B}_{1}$ \\
\hline $\begin{array}{l}\text { Kemampuan Berpikir } \\
\text { Kreatif Rendah }\left(\mathrm{B}_{2}\right)\end{array}$ & $\mathrm{B}_{2} \mathrm{~A}_{1}$ & $\mathrm{~A}_{2} \mathrm{~B}_{2}$ \\
\hline
\end{tabular}

\section{Keterangan :}

$\mathrm{A}=$ Metode pembelajaran

$\mathrm{B}=$ Kemampuan berpikir kreatif

$\mathrm{A}_{1}=$ Metode pembelajaran Peta Pikiran

$\mathrm{A}_{2}=$ Metode pembelajaran Konvensional

$\mathrm{B}_{1}=$ Kemampuan berpikir kreatif tinggi

$\mathrm{B}_{2}=$ Kemampuan berpikir kreatif rendah

Populasi penelitian adalah siswa kelas XI IPS SMA Islam Al-Azhar Kelapa Gading yang berjumlah 56 siswa. Sebelum diberi perlakuan seluruh populasi diberikan kuesioner untuk mendapatkan data skor berpikir kreatif.
Hasilnya kemudian di urutkan masing-masing dari skor tertinggi sampai skor terendah. Kemudian di bagi menjadi 3 kelompok yaitu kelompok skor atas kemampuan berpikir kreatif tinggi $(27 \%)$, kelompok skor bawahkemampuan berpikir kreatif rendah $(27 \%)$. Kemampuan berpikir kreatif tengah $(46 \%)$ tidak diikutkan sebagai sampel namun tetap diperlakukan sebagaimana siswa yang menjadi sampel kelasnya.

Tehnik pengambilan sampel dilakukan secara acak. Sampel berjumlah 32 siswa yang diambil dari dua kelas yang mendapat 
perlakuan berbeda, yaitu kelas eksperimen yang terdiri dari 16 siswa yang diberikan metode pembelajaran peta pikiran dan kelas kontrol yang terdiri dari 16 siswa yang diberikan metode pembelajaran konvensional.

Instrumen yang digunakan adalah tes berpikir kreatif dengan menggunakan skala likert dan tes hasil belajar yang terdiri dari 40 soal pilihan ganda.Validitas instrumen diuji dengan menggunakan rumus product moment dan reliabilitas instrumen diuji menggunakan rumus alpha cronbach.Pengujian hipotesis menggunakan analisis varians dua jalur (ANAVA $2 \times 2$ ) dengan taraf signifikansi $5 \%$. Sebelum data diolah menggunakan
ANAVA $2 \times 2$, dilakukan uji prasyaratyang meliputi uji normalitas dan homogenitas. Uji normalitas menggunakan uji Lilliefors, sedangkan uji homogenitas menggunakan uji Bartlet.Apabila hasil pengujian menunjukkan adanya perbedaan dan interaksi, maka untuk mengetahui kelompok mana yang lebih tinggi hasil belajarnya, dilakukan pengujian dengan menggunakan uji Tuckey.

\section{Hasil Penghitungan}

Hasil penghitungan untuk data hasil belajar meliputi skor maksimum, skor minimum, modus,median, rerata, simpangan baku, tampak pada table berikut ini:

\begin{tabular}{|c|l|c|c|c|c|c|c|c|c|}
\hline \multirow{2}{*}{ No } & \multirow{2}{*}{ Kelompok } & \multicolumn{7}{|c|}{ Data Statistik } & \multirow{2}{*}{ Rentang } \\
\cline { 3 - 10 } & & $\mathbf{n}$ & Max & Min & Me & Mo & $\overline{\mathbf{X}}$ & S & \\
\hline 1 & $\mathrm{~A}_{1}$ & 16 & 36 & 22 & 29.00 & 34.10 & 28.88 & 4.88 & 17 \\
\hline 2 & $\mathrm{~A}_{2}$ & 16 & 30 & 21 & 25.50 & 23.50 & 25.69 & 2.82 & 13 \\
\hline 3 & $\mathrm{~A}_{1} \mathrm{~B}_{1}$ & 8 & 36 & 29 & 33.50 & 35.00 & 33.13 & 2.36 & 7 \\
\hline 4 & $\mathrm{~A}_{1} \mathrm{~B}_{2}$ & 8 & 28 & 22 & 24.17 & 23.50 & 24.63 & 2.07 & 7 \\
\hline 5 & $\mathrm{~A}_{2} \mathrm{~B}_{1}$ & 8 & 27 & 21 & 23.50 & 23.50 & 23.63 & 1.85 & 7 \\
\hline 6 & $\mathrm{~A}_{2} \mathrm{~B}_{2}$ & 8 & 30 & 24 & 28.00 & 28.30 & 27.75 & 1.98 & 7 \\
\hline
\end{tabular}

Keterangan:

$\mathrm{n}$ : Banyaknya

Max : Skor Maksimum

Min : Skor Minimum

Me : Median

Mo : Modus

$\mathrm{X}$ : Rerata

$\mathrm{S}$ : Simpangan Baku

A1 : Kelompok siswa yang mengikuti metode pembelajaran peta pikiran

A2 : Kelompok siswa yang mengikuti metode pembelajaran konvensional

$A_{1} B_{1}$ : Kelompok siswa dengan kemampuan berpikir kreatif tinggi yang mengikuti metode pembelajaran peta pikiran
$A_{1} B_{2}$ : Kelompok siswa dengan kemampuan berpikir kreatif rendah yang mengikuti metode pembelajaran peta pikiran

$\mathrm{A}_{2} \mathrm{~B}_{1}$ : Kelompok siswa dengan kemampuan berpikir kreatif tinggi yang mengikuti metode pembelajaran konvensional

$\mathrm{A}_{2} \mathrm{~B}_{2}$ : Kelompok siswa dengan kemampuan berpikir kreatif rendah yang mengikuti metode pembelajaran konvensional

\section{Uji Normalitas}

Pengujian normalitas dilakukan dengan menggunakan uji Liliefors pada taraf signifikansi $\alpha=0,05$ dengan kriteria: apabila nilai $\mathrm{L}_{\text {hitung }}\left(\mathrm{L}_{\mathrm{o}}\right)$ lebih kecil dari $\mathrm{L}_{\text {tabel }}$ $\left(\mathrm{L}_{\mathrm{t}}\right)$ maka data berdistribusi normal. Hasil 
perhitungannya disajikan pada tabel berikut ini:

\begin{tabular}{|r|l|c|c|c|c|}
\hline No & \multicolumn{1}{|c|}{$\begin{array}{c}\text { Kelompok } \\
\text { Data }\end{array}$} & $\mathbf{n}$ & $\mathbf{L}_{\mathbf{0}}$ & $\mathbf{L}_{\mathbf{t}(\alpha=0,05)}$ & Kesimpulan \\
\hline 1. & Kelompok $\mathrm{A}_{1}$ & 16 & 0,161 & 0,222 & Normal \\
\hline 2. & Kelompok $\mathrm{A}_{2}$ & 16 & 0,163 & 0,222 & Normal \\
\hline 3. & Kelompok $\mathrm{A}_{1} \mathrm{~B}_{1}$ & 8 & 0,111 & 0,313 & Normal \\
\hline 4. & Kelompok $\mathrm{A}_{2} \mathrm{~B}_{1}$ & 8 & 0,178 & 0,313 & Normal \\
\hline 5. & Kelompok $\mathrm{A}_{1} \mathrm{~B}_{2}$ & 8 & 0,170 & 0,313 & Normal \\
\hline 6. & Kelompok $\mathrm{A}_{2} \mathrm{~B}_{2}$ & 8 & 0,139 & 0,313 & Normal \\
\hline
\end{tabular}

Berdasarkan tabel di atas terlihat bahwa nilai Liliefors hasil perhitungan $\left(\mathrm{L}_{\mathrm{o}}\right)$ untuk semua kelompok data lebih kecil dari nilai Liliefors tabel $\left(\mathrm{L}_{\mathrm{t}}\right)$.Hal ini menunjukkan bahwa kelompok sampel penelitian ini berasal dari populasi yang berdistribusi normal, sehingga persyaratan normalitas terpenuhi.

\section{Uji Homogenitas}

Rangkuman hasil perhitungan pengujian homogenitas varians kelompok kombinasi perlakuan dapat dilihat pada tabel di bawah ini:

\begin{tabular}{|c|c|c|c|c|c|c|}
\hline Kelompok & Varians $\left(\mathrm{S}^{2}\right)$ & $\begin{array}{c}\text { Varians } \\
\text { Gabungan }\left(\mathrm{S}_{1}{ }^{2}\right)\end{array}$ & Nilai B & $\mathbf{X}_{\text {hitung }}^{2}$ & $\begin{array}{c}X_{\text {tabel }}^{2} \\
(0,95 ; 3)\end{array}$ & Kesimpulan \\
\hline$A_{1} B_{1}$ & 5,55 & \multirow{4}{*}{4,29} & \multirow{4}{*}{17,71} & \multirow{4}{*}{0,452} & \multirow{4}{*}{7,81} & \multirow{4}{*}{ Homogen } \\
\hline$A_{2} B_{1}$ & 4,27 & & & & & \\
\hline $\mathrm{A}_{1} \mathrm{~B}_{2}$ & 3,41 & & & & & \\
\hline $\mathrm{A}_{2} \mathrm{~B}_{2}$ & 4,93 & & & & & \\
\hline
\end{tabular}

Dari tabel terlihat bahwa $\chi_{\text {hitung }}^{2}$ adalah 0,452 dan $\chi_{\text {tabel }}^{2}$ adalah 7,81 dengan $\alpha=0,05$ dan $\mathrm{dk}{ }_{(0,95 ; 3)}$. Dengan demikian maka varians semua kombinasi perlakuan adalah homogen, sehingga persyaratan homogenitas terpenuhi.

Untuk melihat signifikansi, selanjutnya dilakukan uji lanjut dengan menggunakan Uji Tuckey. Rangkuman hasil perhitungan analisis varians dua jalur (ANAVA $2 \times 2$ ) dengan statistik $\mathrm{F}$ disajikan pada tabel berikut:

\begin{tabular}{|l|c|c|c|c|c|}
\hline \multicolumn{1}{|c|}{ Sumber Varians } & $\mathbf{d b}$ & JK & RK = JK/db & Fh = RKIRKD & Ft 0,05 \\
\hline Metode Pembelajaran (A) & 1 & 81,28 & 81,28 & $18,946^{* *}$ & 4,20 \\
\hline Nerpikir Kreatif (B) & 1 & 38,28 & 38,28 & $8,293^{* *}$ & 4,20 \\
\hline Interaksi (Ax B) & 1 & 318,78 & 318,78 & $74,305^{*}$ & 4,20 \\
\hline Kekeliruan (D) & 28 & 120,13 & 4,29 & & \\
\hline Total Dikoreksi (TR) & 31 & 558,47 & & & \\
\hline
\end{tabular}

Keterangan:

* = signifikan

** = sangat signifikan

$\mathrm{Db}=$ derajat kebebasan
$\mathrm{JK}=$ Jumlah Kuadrat

RK = Rata-rata Kuadrat

$\mathrm{F}_{\mathrm{h}}=\mathrm{F}$ hitung

$\mathrm{F}_{\mathrm{t}}=\mathrm{F}$ tabel 
Pembahasan Hasil Penelitian

\section{a) Hipotesis Pertama}

Dari hasil analisis varians dua jalur (ANAVA 2 x 2), diketahui menolak hipotesis nol yang menyatakan tidak terdapat perbedaan hasil belajar antara siswa yang mengikuti metode pembelajaran peta pikiran dan siswa yang mengikuti metode pembelajaran konvensional ditolak. Hal ini membuktikan bahwa terdapat perbedaan hasil belajar antara siswa yang mengikuti metode pembelajaran peta pikiran dan siswa yang mengikuti metode pembelajaran konvensional. Secara keseluruhan, hasil belajar sejarah siswa yang mengikuti metode pembelajaran peta pikiran lebih tinggi dari siswa yang mengikuti metode pembelajaran konvensional.

Jika dianalisis lebih jauh dengan menggunakan Uji Tuckey ternyata penggunaan metode pembelajaran peta pikiranmemiliki efek yang lebih baik bagi peningkatan hasil belajar sejarah siswa SMA. Siswa memperoleh hasil belajar sejarah yang lebih tinggi jika mengikuti metode pembelajaran petapikiran.

\section{b) Hipotesis Kedua}

Hasilpengujian hipotesis kedua menolak hipotesis nol yang menyatakan tidak terdapat pengaruh interaksi antara metode pembelajaran dan kemampuan berpikir kreatif terhadap hasil belajar sejarah siswa SMA. Hal tersebut berarti terdapat pengaruh interaksi antara metode pembelajaran dan kemampuan berpikir kreatif terhadap hasil belajar sejarah siswa SMA.

\section{c) Hipotesis Ketiga}

Hasil pengujian hipotesis ketiga menolak hipotesis nol yang menyatakan bahwa tidak terdapat perbedaan hasil belajar sejarah antara siswa dengan kemampuan berpikir kreatif tinggi yang mengikuti metode pembelajaran peta pikiran dan siswa yang mengikuti metode pembelajaran konvensional. Siswa yang mengikuti metode pembelajaran peta pikiran dengan kemampuan berpikir kreatif tinggi hasil belajarnya lebih tinggi dari siswa yang mengikuti metode pembelajaran konvensional dengan kemampuan berpikir kreatif tinggi. Hal ini menunjukkan bahwa siswa yang berpikir kreatif tinggi, lebih cocok jika belajar mengikuti metode pembelajaran peta pikiran daripada mengikuti metode pembelajaran konvensional.

Jika dianalisis lebih jauh dengan menggunakan uji Tuckey, maka dapat dilihat bahwa penggunaan metode pembelajaran peta pikiranuntuk siswa yang memiliki kemampuan berpikir kreatif tinggi memiliki efek yang lebih tinggi terhadap hasil belajar sejarah siswa.

\section{d) Hipotesis Keempat}

Hasil pengujian hipotesis menolak hipotesis nol yang menyatakan bahwa tidak terdapat perbedaan hasil belajar sejarah antara siswa dengan kemampuan berpikir kreatif rendah yang belajar mengikuti metode pembelajaran peta pikiran dan siswa yang mengikuti metode pembelajaran konvensional. Siswa yang mengikuti metode pembelajaran peta pikiran dengan kemampuan berpikir kreatif rendah hasil belajarnya lebih rendah dari siswa yang mengikuti metode pembelajaran konvensional dengan kemampuan berpikir kreatif rendah.

Jika dianalisis lebih jauh dengan menggunakan Uji Tuckey ternyata penggunaan metode pembelajaran peta pikiranmemiliki efek yang lebih rendah bagi peningkatan hasil belajar sejarah siswa SMA. Siswa yang memiliki kemampuan berpikir kreatif rendah memperoleh hasil belajar sejarah yang lebih tinggi jika mengikuti metode pembelajaran konvensional daripada jika diberikan metode pembelajaran peta pikiran. 


\section{Kesimpulan}

1. Berdasarkan hasil pengujian hipotesis, penelitian ini membuktikan bahwa hasil belajar sejarah siswa yang mengikuti metode pembelajaran peta pikiran lebih tinggi dari siswa yang mengikuti metode pembelajaran konvensional.

2. Terdapat pengaruh interaksi antara metode pembelajaran dan kemampuan berpikir kreatif terhadap hasil belajar sejarah siswa.

3. Hasil belajar sejarah siswa dengan kemampuan berpikir kreatif tinggi yang mengikuti metode pembelajaran peta pikiran lebih tinggi dari siswa yang mengikuti metode pembelajaran konvensional.

4. Hasil belajar sejarah siswa dengan kemampuan berpikir kreatif rendah yang mengikuti metode pembelajaran konvensional lebih rendah dari siswa yang mengikuti metode pembelajaran konvensional.

\section{Rekomendasi}

1. Dalam proses pembelajaran sejarah, guru dapat menggunakan metode pembelajaran peta pikiran maupun metode pembelajaran konvensional.

2. Dalam menerapkan metode pembelajaran peta pikiran dan konvensional, guru sebaiknya memperhatikan tingkat kemampuan berpikir kreatif siswa dalam meningkatkan hasil belajar.

3. Dari hasil penelitian ini, ternyata metode pembelajaran peta pikiran dapat meningkatkan hasil belajar sejarah siswa yang memiliki kemampuan berpikir kreatif tinggi dan metode pembelajaran konvensional dapat meningkatkan hasil belajar sejarah siswa yang memiliki kemampuan berpikir kreatif rendah. Melihat situasi seperti ini, sebaiknya guru lebih selektif dalam memilih metode pembelajaran bagi siswa dengan tingkat kemampuan berpikir kreatif yang berbeda.
4. Setelah menentukan metode pembelajaran, sebaiknya guru juga mengembangkan bahan ajar, media pembelajaran, dan faktor pendukung lainnya sehingga tujuan pembelajaran dapat dicapai dengan efektif.

\section{Daftar Pustaka}

Anderson, Lorin W dan David, R. Krathwohl (Editor). 2010. Kerangka Landasan Untuk Pembelajaran, Pengajaran, dan Asesmen. Yogyakarta: Pustaka Pelajar,

Buzan, Tony dan Buzan Bary. 2004. Memahami Peta Pikiran. Batam: Penerbit Interaksara.

Buzan, Tony. 2006. Buku Pintar Peta Pikiran. Jakarta: Gramedia.

Buzan, Tony. 2007. Buku Pintar Mind Map Untuk Anak. Jakarta: P. T. Gramedia Pustaka Utama.

De Porter, Bobbi dan Mike Hernacki. 2013. Quantum Learning: Membiasakan Belajar Nyaman dan Menyenangkan. Bandung: Penerbit Kaifa.

Halpern, D. F. 1996. Thought and Knowledge: An Introduction to Critical Thinking (3rd ed.). New Jersey: Lawrence Erlbaum Associatio Publishers.

Hamruni. 2012. Strategi Pembelajaran. Yogyakarta: Insan Mandiri.

Hyerle, David N dan Larry Alper. 2012.Peta Pemikiran. Jakarta: P. T. Indeks.

Hasan, Hamid. 2012. Pendidikan Sejarah Indonesia: Isu dalam Ide dan Pembelajaran. Bandung: Rizqi Press.

Jones, Vern dan Louise Jones. 2012. Manajemen Kelas Komprehensif. Jakarta: Kencana. 
Kuswana, Wowo Sunaryo. 2012.Taksonomi Kognitif Perkembangan Ragam Berpikir. Bandung: PT. Remaja Rosdakarya.

Melvin. L Silberman. 2013, Active Learning: 101 Cara Belajar Siswa Aktif. Bandung: Nusamedia.

M. S. Suharnan. 2005. Psikologi Kognitif. Surabaya: Penerbit Srikandi.

Munandar, Utami. 2009.Pengembangan Kreativitas Anak Berbakat. Jakarta: PT. Rineke Cipta.
Nurhayati, Eti. 2011.Psikologi Pendidikan Inovatif. Jogjakarta: Pustaka Pelajar.

Suprihatiningrum, Jamil. 2013. Strategi Pembelajaran; Teori dan Aplikasi. Yogyakarta: Ar Ruzz Media.

Rita, Richey. 2000.The Legacy of Robert Gagne. New York: sycrause University.

Wycoff J. 2004. Menjadi Super Kreatif Melalui Metode Pemetaan Pikiran. Jakarta: Kaifa. 